\title{
Frateuria, a New Genus for "Acetobacter aurantius"
}

\author{
J. SWINGS, M. GILLIS, K. KERSTERS, P. DE VOS, F. GOSSELÉ, AND J. DE LEY \\ Laboratorium voor Microbiologie en microbiële Genetica, Rijksuniversiteit, B-9000 Ghent, Belgium
}

\begin{abstract}
The properties and taxonomic positions of 11 strains previously identified as members of "Acetobacter aurantius Kondô and Ameyama" (this name is not on the Approved Lists) were reexamined. For each we determined about 100 phenotypic features, the protein gel electropherograms, and the parameters of deoxyribonucleic acid: ${ }^{14} \mathrm{C}$-ribosomal ribonucleic acid (DNA: $\left[{ }^{14} \mathrm{C}\right] \mathrm{rRNA}$ ) hybrids. The 11 strains fell into three taxonomically distinct groups. Strain IFO 3248 was the only one which belonged in Acetobacter. Strain IFO 3246 was an atypical Gluconobacter. The remaining nine strains formed a tight cluster, with very similar phenotypic features and protein gel electropherograms. Taxonomically, this cluster is quite removed from Gluconobacter and Acetobacter, and the properties of its DNA:rRNA hybrids suggest that it is closer to Pseudomonas Section I (R. E. Buchanan and N. E. Gibbons [ed.], Bergeys Manual of Determinative Bacteriology, 8th ed.) and Xanthomonas. We propose the name Frateuria gen. nov. for this cluster, with Frateuria aurantia sp. nov. as the type species and IFO 3245 as the type strain. An extensive phenotypic description and minimal standards of the new genus are given, as is the phenotypic differentiation from Gluconobacter and Acetobacter.
\end{abstract}

The name "Acetobacter aurantium" (sic) was proposed by Kondô and Ameyama (17) to refer to four strains of acetic acid bacteria isolated from Lilium auratum Lindl. Because these strains share diagnostic features with Gluconobacter as well as with Acetobacter, Asai (3) and Asai et al. (4) judged that it was difficult to assign them to either of these two genera and therefore referred to them as "intermediate" strains. Additional characteristics of these strains were given by Ameyama and Kondô (1, 2). Yamada et al. (24) showed that these strains produce ubiquinone Q8, whereas Gluconobacter possesses ubiquinone Q10 and Acetobacter possesses ubiquinone Q9. Yamada et al. (25) isolated and characterized six additional polarly flagellated intermediate strains from Rubus parvifolius.

The taxonomic position of these strains has been obscure to now. They have not been considered to belong to either Acetobacter, because of their polar flagellation and their ubiquinone $\mathrm{Q} 8$, or to Gluconobacter, because of their oxidation of lactate, their lack of requirement for growth factors, their oxidation of amino acids, and their characteristic ubiquinone $Q 8$, but they were believed to lie somewhere in between these two genera. The problematic taxonomic status of these strains is further illustrated by the complete lack of any reference to them in Sneath and Skerman's list of reference strains of bacteria (22), the Index Bergeyana (8), the eighth edition of Bergey's Manual (7), and the Ap- proved Lists of Bacterial Names (21). The name "Acetobacter aurantius" thus has no standing in nomenclature. Fourteen " $A$. aurantius" strains have been mentioned in the literature, and 11 of them are available from the culture collection at the Institute for Fermentation (IFO), Osaka, Japan, where they are held as " $A$. aurantius" IFO $3245,3246,3247,3248,3249$, $13328,13329,13330,13331,13332$, and 13333.

As part of a current extensive reinvestigation of the acetic acid bacteria, we examined the " $A$. aurantius" strains by deoxyribonucleic acid:ribosomal ribonucleic acid (DNA:rRNA) hybridizations to establish their taxonomic position at the generic and suprageneric levels (15), by protein gel electrophoresis to reveal the internal fine structure of the taxon (16; K. Kersters and J. De Ley, in M. Goodfellow and R. Board [ed.], Impact of Modern Methods on Classification and Identification, in press), and by an extensive phenotypic analysis. On the basis of our data, we propose, in the discussion below, a new genus and species name, Frateuria aurantia, for strains IFO $3245,3247,3249$, and 13328 to 13333. Strain IFO 3246 was found to be a strain of Gluconobacter, and strain IFO 3248, a strain of Acetobacter.

\section{MATERIALS AND METHODS}

Bacterial strains. The 11 strains used in this study were obtained from the Institute of Fermentation, Osaka, Japan (see Table 1).

Nutritional, physiological, and biochemical 
TABLE 1. Organisms used in this study

\begin{tabular}{|c|c|c|c|}
\hline Strain received as & $\begin{array}{c}\text { Name given in the present } \\
\text { paper }\end{array}$ & Strain no. & Isolated from \\
\hline "Acetobacter aurantius" & Frateuria aurantia & $\begin{array}{l}\text { IFO } 3245(=\mathrm{G}-6= \\
\text { Kondô } 67)\end{array}$ & $\begin{array}{l}\text { Lilium auratum, Ja- } \\
\text { pan (17) }\end{array}$ \\
\hline "A. aurantius" & Frateuria aurantia & $\begin{array}{l}\text { IFO } 3247 \text { (= Kondô } 71 \\
\quad=\text { ATCC } 12301)\end{array}$ & $\begin{array}{l}\text { Lilium auratum, Ja- } \\
\text { pan (17) }\end{array}$ \\
\hline "A. aurantius" & Frateuria aurantia & IFO 3249 (= Kondô 69) & $\begin{array}{l}\text { Lilium auratum, Ja- } \\
\text { pan (17) }\end{array}$ \\
\hline "A. aurantius" & Frateuria aurantia & $\begin{array}{l}\text { IFO } 13328 \text { (= Yamada } \\
\text { 5) }\end{array}$ & $\begin{array}{l}\text { Fruit of Rubus parvi- } \\
\text { folius (raspberry) } \\
\text { Japan (25) }\end{array}$ \\
\hline "A. aurantius" & Frateuria aurantia & $\begin{array}{l}\text { IFO } 13329 \text { (= Yamada } \\
\text { I1) }\end{array}$ & $\begin{array}{l}\text { Fruit of Rubus parvi- } \\
\text { folius (raspberry) } \\
\text { Japan (25) }\end{array}$ \\
\hline "A. aurantius" & Frateuria aurantia & $\begin{array}{l}\text { IFO } 13330 \text { (= Yamada } \\
20)\end{array}$ & $\begin{array}{l}\text { Fruit of Rubus parvi- } \\
\text { folius (raspberry) } \\
\text { Japan (25) }\end{array}$ \\
\hline "A. aurantius" & Frateuria aurantia & $\begin{array}{l}\text { IFO } 13331 \text { (= Yamada } \\
\quad 28)\end{array}$ & $\begin{array}{l}\text { Fruit of } R u b u s \text { parvi- } \\
\quad \text { folius (raspberry) } \\
\text { Japan (25) }\end{array}$ \\
\hline "A. aurantius" & Frateuria aurantia & $\begin{array}{l}\text { IFO } 13332 \text { (= Yamada } \\
\quad 38)\end{array}$ & $\begin{array}{l}\text { Fruit of Rubus parvi- } \\
\text { folius (raspberry) } \\
\text { Japan (25) }\end{array}$ \\
\hline "A. aurantius" & Frateuria aurantia & $\begin{array}{l}\text { IFO } 13333 \text { (= Yamada } \\
130 \text { ) }\end{array}$ & $\begin{array}{l}\text { Fruit of Rubus parvi- } \\
\text { folius (raspberry) } \\
\text { Japan (25) }\end{array}$ \\
\hline "A. aurantius" & Gluconobacter sp. & $\begin{array}{l}\text { IFO } 3246 \mathrm{t}_{1}{ }^{a} \text { (= Kondô } \\
70)\end{array}$ & $\begin{array}{l}\text { Lilium auratum, Ja- } \\
\text { pan (17) }\end{array}$ \\
\hline "A. aurantius" & Acetobacter sp. & IFO 3248 (= Kondô 68 ) & $\begin{array}{l}\text { Lilium auratum, Ja- } \\
\text { pan (17) }\end{array}$ \\
\hline
\end{tabular}

${ }^{a}$ Strain IFO 3246 displayed two stable colony types $\left(t_{1}, t_{2}\right)$ upon plating. Only strain IFO $3246 t_{1}$ was used, because both types showed identical protein electropherograms.

tests. The cultures were grown either on a medium containing (wt/vol) 5\% D-glucose, 1\% yeast extract (Oxoid), $3 \% \mathrm{CaCO}_{3}$, and $2.5 \%$ agar or on one with $2.5 \%$ mannitol, $0.5 \%$ yeast extract (Oxoid), $0.3 \%$ peptone (Oxoid), and 2.5\% agar. The Hoyer media were used as modified by Frateur (14) with either 3\% (vol/vol) ethanol, glucose, or mannitol. To test for tolerance towards different temperatures and $\mathrm{NaCl}$, glucose, and ethanol concentrations, a basal medium containing 5\% D-glucose and $0.5 \%$ yeast extract (Oxoid) was used. Acid production from different carbon sources was detected in the medium of Asai et al. (4). The oxidation and overoxidation of ethanol to acetic acid, and to $\mathrm{CO}_{2}$ and water, respectively, were tested by the method of Frateur (14). Gelatinase activity was tested on a medium containing (wt/vol) $2 \%$ mannitol, $0.1 \%$ D-glucose, $0.5 \%$ yeast extract (Oxoid), $0.3 \%$ peptone (Oxoid), and $12 \%$ gelatin. The reduction of nitrates was tested on a medium containing $5 \%$ D-glucose, $0.5 \%$ yeast extract (Oxoid), and $0.1 \% \mathrm{KNO}_{3}$. Indole formation was tested in a medium containing $1 \%$ tryptone (Oxoid), $0.2 \%$ yeast extract (Oxoid), and 1\% D-glucose; $\mathrm{H}_{2} \mathrm{~S}$ formation was detected by lead acetate paper strips in a medium with $5 \%$ D-glucose, $0.5 \%$ peptone (Oxoid), $0.5 \%$ yeast extract (Oxoid), $0.1 \%$ L-cysteine, and $0.05 \%$ $\mathrm{Na}_{2} \mathrm{SO}_{4}(\mathrm{pH}$ 7). Acetate and lactate oxidation and ketogenesis from glycerol, mannitol, and sorbitol were examined by the method of Frateur (14). For growth factor requirements, the procedure of Ameyama and
Kondô (1) was followed. Asai and Shoda's (5) ferric chloride reaction was utilized. The oxidase reaction was tested on filter paper soaked in $1 \%$ dimethyl-pphenylenediamine. To test for catalase activity, young colonies ( 3 days old) were suspended in $10 \%$ (vol/vol) $\mathrm{H}_{2} \mathrm{O}_{2}$. The medium for the formation of ketogluconic acid consisted of $0.3 \%$ yeast extract (Oxoid) and $3 \%$ D-glucose. The 2-keto-, 5-keto-, and 2,5-diketogluconic acids were separated by thin-layer chromatography on microcrystalline (Merck) cellulose with ethyl acetatewater-acetic acid-formic acid (18:4:3:1, vol/vol) (6). The chromatograms were developed by use of the 0 phenylenediamine spray reagent $(9,18)$.

Polyacrylamide gel electrophoresis of soluble proteins and numerical analysis of the electropherograms. Cells were grown for $40 \mathrm{~h}$ at $28^{\circ} \mathrm{C}$ in Roux bottles on the glucose-yeast extract-CaCO${ }_{3}$-agar medium. Cell-free extracts were prepared as described by Kersters and De Ley (16). The soluble protein fraction of each strain was dialyzed against 1 liter of 6.4 $\mathrm{mM}$ tris(hydroxymethyl)aminomethane-hydrochloride ( $\mathrm{pH}$ 9.2). Polyacrylamide gel electrophoresis, densitometry, and photography of the stained gels, normalization of the densitometric tracings, computerassisted calculations of the Pearson-product moment correlation coefficient $r$, and clustering were performed as described previously (16). Each protein extract was investigated in at least three different electrophoretic experiments. 
DNA:rRNA hybridizations. The following strains were used: IFO $3246 \mathrm{t}_{1}, 3247,3248,3249,13330$, and 13333. Cell growth, DNA preparation, fixation of DNA on filters, chemical determination of the amount of DNA on filter, the preparation of $\left[{ }^{14} \mathrm{C}\right] \mathrm{rRNA}$, and the hybridizations between fixed, single-stranded, highmolecular-weight DNA and $16 \mathrm{~S}$ or $23 \mathrm{~S}\left[{ }^{14} \mathrm{C}\right] \mathrm{rRNA}$ were carried out as described by De Ley and De Smedt (10). Reference $\left[{ }^{14} \mathrm{C}\right]$ rRNA was prepared from the type strains (22) of Acetobacter aceti subsp. aceti (NCIB 8621) (colony type $\mathrm{t}_{1}$ ), Gluconobacter oxydans subsp. oxydans NCIB 9013 (= ATCC 19357), and Pseudomonas fluorescens ATCC 13525 and from Xanthomonas campestris NCPPB 528. From each hybrid the thermostability, expressed as $T_{m(e)}$ (the temperature at which half of the DNA:rRNA hybrid was denatured in $1.5 \times \mathrm{SSC}$ [SSC, $0.15 \mathrm{M} \mathrm{NaCl}-0.015 \mathrm{M}$ sodium citrate, $\mathrm{pH} 7.0 \mathrm{]}-20 \%$ formamide), and the percent rRNA binding (the amount of $\left[{ }^{14} \mathrm{C}\right] \mathrm{rRNA}$, in micrograms, hybridized with $100 \mu \mathrm{g}$ of single-stranded, highmolecular-weight DNA) were measured.

\section{RESULTS}

Phenotypic features. The properties of strains IFO 3245, 3247, 3249, 13328, 13330, 13331, and 13333 will be described first; strains IFO $3246 t_{1}$ and 3248 will be treated separately. Most of the features of these strains are shown in Table 2. We shall only clarify a few additional points here. Not all of the strains were motile. The actively motile strain 13331 had very thin polar flagella when stained by Rhodes' (19) flagella-staining technique. This confirmed the observations by the Japanese authors $(2,4,25)$. Good growth was obtained on glucose-yeast extract- $\mathrm{CaCO}_{3}$ agar. Strains 3249 and 13333 did not form a water-soluble, yellow-brown pigment. All strains tested grew easily without any growth factor. Some strains grew in yeast extract, in peptone broth, or in Hoyer media. Ammonium was utilized in a Hoyer medium containing mannitol as the sole carbon source. All strains g $g_{1}$ w very well on Casamino Acids, in contrast with other acetic acid bacteria, which do not. This phenomenon could also be deduced from Table 3 of Ameyama and Kondô (2). The oxidation of lactate to $\mathrm{CO}_{2}$ was demonstrated by oxidograms. $\mathrm{CaCO}_{3}$ precipitated when the strains were grown on a Ca-lactate-yeast extract-agar medium. In a liquid medium, every strain formed acid from ethanol, the final $\mathrm{pH}$ sometimes dropping down to 3.8. It was difficult, however, to get an unequivocal answer as to whether all strains formed acetic acid on ethanol-yeast extract$\mathrm{CaCO}_{3}$ plates. The oxidation of acetate was reported by Ameyama and Kondô (2) and Yamada et al. (25), but in the original description (17) it was clearly stated that the organisms did not oxidize acetic acid. From the respirometric data of Ameyama and Kondô (2), one can conclude that these strains possess a distinct but very weak ability to oxidize acetate. On Frateur's acetate oxidograms or in the overoxidation test on ethanol-yeast extract- $\mathrm{CaCO}_{3}$ medium, we found all strains to be negative. These contradictory results suggest that the eventual oxidation of acetate is very weak and that its detection depends on the sensitivity of the method. The ketogenic activity is another example of a weak or doubtful phenomenon. Ameyama and Kondô (2) found no ketogenic activity with strains 3245 , $3246,3247, \alpha$, and $\beta$. Yamada et al. (25) retested these strains and found no reaction. Asai et al. (4) had also noted a negative result with strains 3245 and 3246 , but Asai (3) reported a positive reaction. In our hands a positive, but weak, ketogenic reaction was found with glycerol, mannitol, and sorbitol for all the strains tested. The test conditions were probably different, so that a slightly positive reaction might appear to be negative to some. We incubated the cells for $2 \mathrm{~h}$ at $30^{\circ} \mathrm{C}$, covered the plates with Benedict reagent, and left them for $3 \mathrm{~h}$ at $30^{\circ} \mathrm{C}$ (for glycerol) or at $45^{\circ} \mathrm{C}$ (for sorbitol and mannitol). The Japanese authors attached great importance to the ferric chloride reaction. According to Yamada et al. (25), all of the " $A$. aurantius" strains gave a positive ferric chloride reaction, but we found no reaction for strains IFO 13328, 13330, 13331, and 13333. The ferric chloride reaction has some inconveniences: it is rather unspecific, because it reacts with phenols, enols, oximes and hydroxamic acids (20), and the different shades of red, violet, and brown are difficult to interpret as a definite positive or negative reaction; this is particularly true for the " $A$. aurantius" strains which produce water-soluble brown pigments. Kondô and Ameyama (17) stated that gluconic acid and a strong reducing acid, but not 5-ketogluconic acid, were formed from glucose. Subsequently, the formation of ketogluconic acids has not been mentioned. We established the production of both 2-keto- and 2,5-diketogluconic acids but not 5-ketogluconic acid by the seven strains tested. This combination of keto acids also occurs-although very rarely-with Gluconobacter and Acetobacter (15a). We detected acid formation from ethanol, glycerol, Darabinose, D-xylose, D-ribose, D-fructose, D-glucose, D-galactose, and D-mannose, in agreement with previous observations $(4,17,25)$. The production of acid from D-glucose and D-xylose was particularly manifest, since the $\mathrm{pH}$ always dropped below 4 . We found the "A. aurantius" strains to grow at low $\mathrm{pH}$ values ( $\mathrm{pH} 3.6)$, as was previously observed by Asai et al. (4) and Yamada et al. (25). These authors also grew them at $37^{\circ} \mathrm{C}$, but we could not confirm this for all of the strains. At $34^{\circ} \mathrm{C}$, however, the seven strains 
TABle 2. Phenotypic features of seven F. aurantia strains, Acetobacter sp. IFO 3248 and Gluconobacter sp. IFO $3246 t_{1}{ }^{a}$

\begin{tabular}{cccccccccccc}
\hline & \multicolumn{1}{c}{ Strain no. } \\
\cline { 2 - 8 } & Feature & IFO & IFO & IFO & IFO & IFO & IFO & IFO & IFO & IFO & \\
& & 3245 & 3247 & 3249 & 13328 & 13330 & 13331 & 13333 & 3248 & $3246 \mathrm{t}_{1}$ \\
\hline
\end{tabular}

Morphology on glucose-yeast extract-

\section{$\mathrm{CaCO}_{3}$ :}

Good growth

Dark colony

Pale colony

Glistening colony

Flat colony

Diameter of colony $\geqslant 3 \mathrm{~mm}$

Soluble brown pigment

Cell morphology:

Gram reaction

Rod

Ovoid

Filament

Chain

Pairs of cells

Diameter of cells $\leqslant 0.7 \mu \mathrm{m}$

Motility

Growth on or in:

Yeast extract broth

Peptone broth

Litmus milk

Frateur's Hoyer medium-ethanol

Frateur's Hoyer medium-glucose

Frateur's Hoyer medium-mannitol

$5 \%$ Glucose- $0.5 \%$ yeast extract -0.5 to $2 \% \mathrm{NaCl}$

$5 \%$ Glucose- $0.5 \%$ yeast extract $-1 \%$ ethanol

$5 \%$ Glucose- $0.5 \%$ yeast extract- $2 \%$ ethanol

5\% Glucose- $0.5 \%$ yeast extract- $5 \%$ ethanol

$5 \%$ Glucose $-0.5 \%$ yeast extract- $10 \%$ ethanol

$5 \%$ Glucose $-0.5 \%$ yeast extract at $4^{\circ}$ $\mathrm{C}$

$5 \%$ Glucose- $0.5 \%$ yeast extract at $30^{\circ} \mathrm{C}$

$5 \%$ Glucose-0.5\% yeast extract at $34^{\circ} \mathrm{C}$

$5 \%$ Glucose- $0.5 \%$ yeast extract at $37^{\circ} \mathrm{C}$

$5 \%$ Glucose- $0.5 \%$ yeast extract at pH 3.15

$5 \%$ Glucose- $0.5 \%$ yeast extract at pH 3.6

$5 \%$ Glucose- $0.5 \%$ yeast extract at pH 4.75-8.1

$0.5 \%$ Yeast extract-20\% glucose

$0.5 \%$ Yeast extract-25\% glucose

$0.5 \%$ Yeast extract-30\% glucose

$0.5 \%$ Yeast extract-35 to $40 \%$ glucose

Anaerobic growth

Final $\mathrm{pH}$ in $\mathrm{D}$-glucose $\leqslant 4$

Final pH in $\mathrm{D}$-xylose $\leqslant 4$

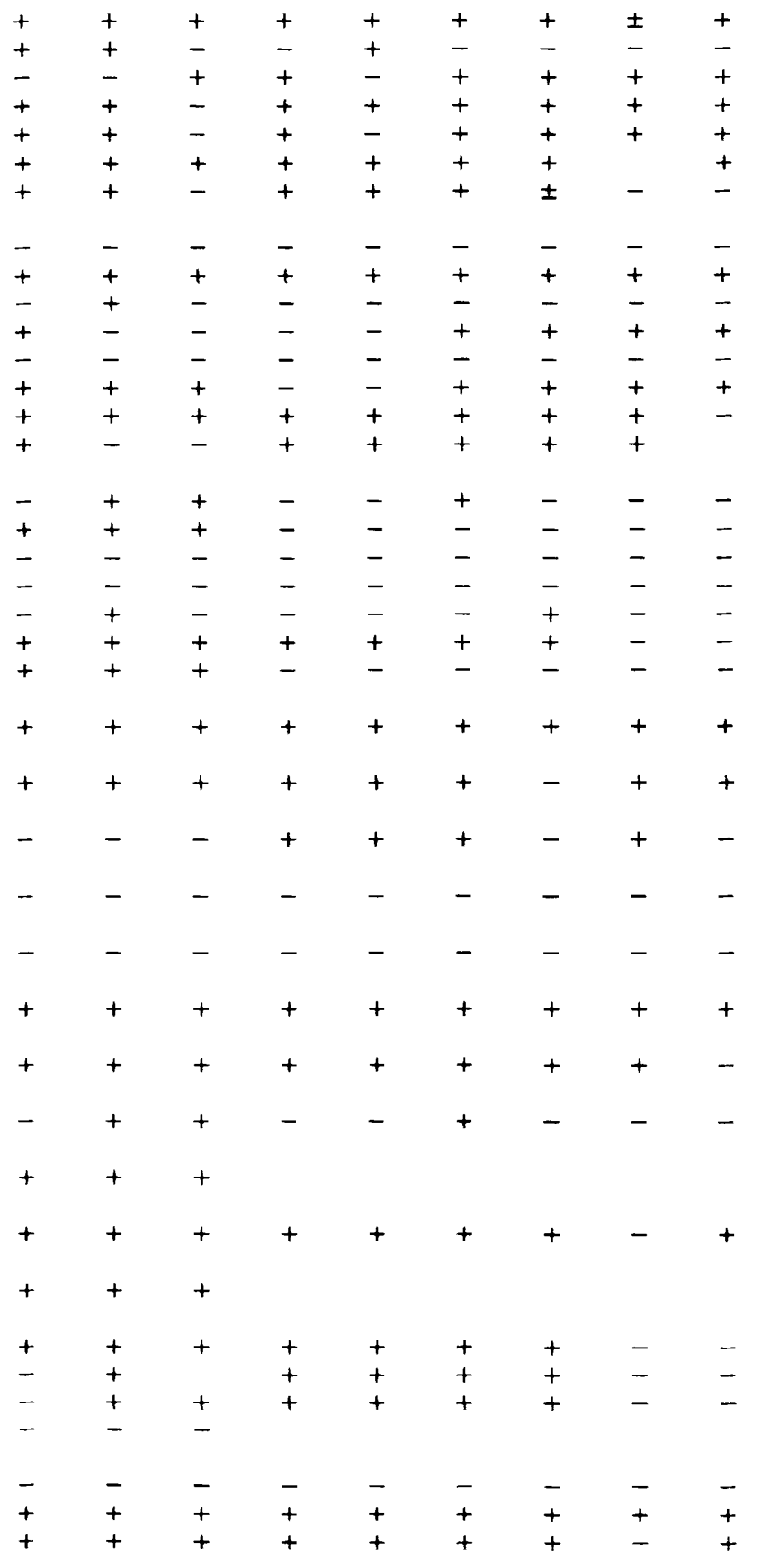


TABLE 2-continued

\begin{tabular}{cccccccccccc}
\hline & \multicolumn{1}{c}{ Strain no. } \\
\cline { 2 - 8 } & Feature & IFO & IFO & IFO & IFO & IFO & IFO & IFO & IFO & IFO & \\
& & 3245 & 3247 & 3249 & 13328 & 13330 & 13331 & 13333 & 3248 & $3246 \mathrm{t}_{1}$ \\
\hline
\end{tabular}

Requirement for growth factors

p-Aminobenzoic acid

Thiamine

Nicotinic acid

Pantothenic acid

Biochemical reactions:

\section{Oxidase}

Catalase

Reduction of nitrates

Formation of indole

Formation of $\mathrm{H}_{2} \mathrm{~S}$

Ferric chloride reaction

Ketogenesis with:

Glycerol

D-Mannitol

D-Sorbitol

Oxidogram on:

\section{Acetate}

\section{Lactate}

\section{Gelatinase}

Acid from ethanol (Frateur)

Overoxidation of ethanol (Frateur)

Formation of 5-ketogluconic acid

Formation of 2-ketogluconic acid

Formation of 2,5-diketogluconic

$\begin{array}{lllllll}- & - & - & - & - & - & - \\ - & - & - & - & - & - & - \\ - & - & - & - & - & - & - \\ - & - & - & - & - & - & -\end{array}$

$\begin{array}{lll}- & & - \\ - & & - \\ - & & + \\ & & + \\ + & - & - \\ - & - & + \\ - & - & - \\ + & - & - \\ - & - & - \\ & & \\ + & - & + \\ + & - & + \\ + & - & + \\ & & \\ - & - & - \\ + & - & - \\ - & - & - \\ + & + & - \\ - & + & - \\ - & - & + \\ + & + & + \\ + & - & -\end{array}$

Acid from:

Ethanol

Glycerol

$m$-Erythritol

D-Arabinose

D-Ribose

D-Xylose

L-Rhamnose

D-Fructose

D-Galactose

D-Glucose

D-Mannose

L-Sorbose

Mannitol

D-Sorbitol

D-Cellobiose

D-Lactose

Maltose

Sucrose

Raffinose

Dextrin

Starch

Susceptibility to:

Kanamycin $(30 \mu \mathrm{g})$

Streptomycin $(10 \mu \mathrm{g})$

Tetracycline $(30 \mu \mathrm{g})$

Novobiocin $(30 \mu \mathrm{g})$

Ampicillin $(10 \mu \mathrm{g})$

Nalidixic acid $(30 \mu \mathrm{g})$

Gentamicin $(10 \mu \mathrm{g})$

Chloramphenicol $(30 \mu \mathrm{g})$

Cephaloridine $(25 \mu \mathrm{g})$ 
TABLE 2-continued

\begin{tabular}{lccccccccc}
\hline & \multicolumn{10}{c}{ Feature } & \multicolumn{10}{c}{ Strain no. } \\
\cline { 2 - 8 } & IFO & IFO & IFO & IFO & IFO & IFO & IFO & IFO & IFO \\
& 3245 & 3247 & 3249 & 13328 & 13330 & 13331 & 13333 & 3248 & $3246 \mathrm{t}_{\text {I }}$ \\
\hline Bacitracin $(10 \mathrm{U})$ & - & - & - & - & - & - & - & - & - \\
Penicillin G $(10 \mathrm{U})$ & - & - & - & - & - & - & - & - & - \\
Erythromycin $(10 \mu \mathrm{g})$ & - & - & - & - & - & - & - & - & - \\
Lincomycin $(2 \mu \mathrm{g})$ & - & - & - & - & - & - & - & - & - \\
Colistin sulfate $(10 \mu \mathrm{g})$ & - & - & - & - & - & - & - & - & - \\
Fusidic acid $(10 \mu \mathrm{g})$ & - & - & - & - & - & - & - & - & - \\
Nitrofurantoin $(200 \mu \mathrm{g})$ & - & - & - & - & - & - & - & - & - \\
Methicillin $(10 \mu \mathrm{g})$ & - & - & - & - & - & - & - & - & - \\
Neomycin $(30 \mu \mathrm{g})$ & - & - & - & - & - & - & - & - & - \\
Polymyxin B $(300 \mathrm{U})$ & - & - & - & - & - & - & - & - & - \\
Sulfafurazole $(100 \mu \mathrm{g})$ & - & - & - & - & - & - & - & - \\
\hline
\end{tabular}

${ }^{a}$ These strains were received as "Acetobacter aurantius."

grew well. Kondô and Ameyama (17) characterized "A. aurantius" as a gelatin liquefier, but in a later publication (2) they reported no gelatin liquefaction for strains IFO $3245,3246,3247$, $3248, \alpha, \beta$, and $\gamma$. We found no gelatin liquefaction. We also examined a series of features that was not tested by other authors. The sensitivity to 0.5 to $2 \% \mathrm{NaCl}$ was determined, and strains 3245,3247 , and 3249 grew very well; the others did not. Ethanol concentrations above 5\% were not tolerated. Five of the seven strains grew in 25 to $30 \%$ glucose concentrations. All of the " $A$. aurantius" strains produced catalase and $\mathrm{H}_{2} \mathrm{~S}$; they do not possess oxidase, do not produce indole, and do not reduce nitrates. Acetic acid bacteria do not produce $\mathrm{H}_{2} \mathrm{~S}$.

Strain IFO $3246 t_{1}$ is very different from the other strains described here. It did not grow at or above $34^{\circ} \mathrm{C}$, in $20 \%$ or more glucose, or in Hoyer's medium with mannitol. It did not produce brown pigment on glucose-yeast extract$\mathrm{CaCO}_{3}$ agar; it required nicotinic acid and pantothenate as growth factors; it was not susceptible to $10 \mu \mathrm{g}$ of ampicillin; it produced 5-ketogluconic but not 2,5-diketogluconic acid; it did not produce $\mathrm{H}_{2} \mathrm{~S}$; it did not produce $\mathrm{CO}_{2}$ from lactate or detectable acid from ethanol, mesoerythritol, or mannose; and it produced acid from L-sorbose, mannitol, sorbitol, raffinose, and dextrin (Table 2). Phenotypically, IFO $3246 \mathrm{t}_{1}$ is a Gluconobacter, but an atypical one because it forms no detectable acetic acid from ethanol.

Strain IFO 3248 is likewise very different from the above-mentioned " $A$. aurantius" strains (Table 2). It grew very poorly on glucose or on Hoyer-mannitol media and did not form a watersoluble brown pigment. From ethanol it produced acetic acid, which was further oxidized to $\mathrm{CO}_{2}$ and water; it did not form $\mathrm{H}_{2} \mathrm{~S}$ and was not ketogenic. This strain is an atypical Acetobacter because it does not oxidize lactate to $\mathrm{CO}_{2}$ and water. Recently, this strain was examined at the IFO (I. Banno, personal communication): it grew weakly, produced no diffusible pigment on glucose medium, was peritrichous, was not ketogenic on glycerol, acidified ethanol, oxidized lactate very slowly but not acetate, and could not utilize $\mathrm{NH}_{4}{ }^{+}$as a sole source of nitrogen. The IFO confirmed our conclusion that it was different from the other " $A$. aurantius" strains studied.

Protein electropherograms. Forty-four normalized scans of protein electropherograms from nine " $A$. aurantius" strains were clustered by the unweighted average-pair group method. The lower limits of reproducibility were as follows: for strains 3245 (6 gels) and 3247 (6 gels), $r=0.98$; for strain 3249 ( 3 gels), $r=0.99$; and for strains 13328 to 13333 (29 gels), $r=0.97$. The most typical electropherogram of each strain (23) was used for the final clustering represented in Fig. 1. The electrophoretic protein patterns of strains IFO 3249, 13328, 13329, 13330, 13331, 13332 , and 13333 are almost indistinguishable from each other and cluster at $r \geq 0.97$. Their electropherograms are very similar to, but not identical with, those of strains 3245 and 3247 . The protein electropherograms of strains IFO $3246 t_{1}$ and IFO 3248 are completely different from those of the nine strains mentioned above and from each other.

DNA: $\left[{ }^{14} \mathrm{C}\right] \mathrm{rRNA}$ hybridizations. The results of the DNA: $\left[{ }^{14} \mathrm{C}\right] \mathrm{rRNA}$ hybridizations are shown in Table 3 . The hybridizations between labeled rRNA and the DNAs from the reference Acetobacter, Gluconobacter, Pseudomonas, and Xanthomonas strains are reported as controls. The DNA:rRNA hybrids of the "A. aurantius" strains IFO 3247, 3249, 13330, and 13333 have similar thermal stabilities versus each reference 


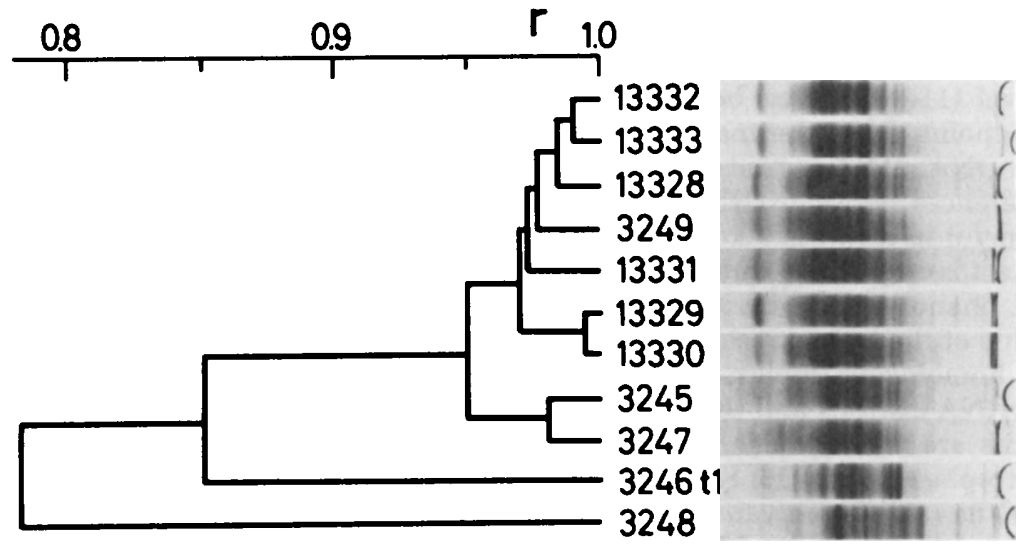

Fig. 1. Quantitative correlations between normalized electropherograms of soluble proteins from nine Frateuria aurantia strains, Gluconobacter sp. IFO $3246 t_{1}$, and Acetobacter sp. IFO 3248 . All strains were received as "Acetobacter aurantius."

TABLE 3. Properties of the DNA: $\left[{ }^{14} C\right] r R N A$ hybrids between $\left[{ }^{14} C\right] r R N A$ from several type and reference strains ${ }^{a}$ and DNA from four Frateuria aurantia strains ${ }^{b}$

\begin{tabular}{|c|c|c|c|c|c|c|c|c|}
\hline \multirow{3}{*}{ DNA from: } & \multicolumn{8}{|c|}{ Source of $\left[{ }^{14} \mathrm{C}\right] \mathrm{rRNA}$} \\
\hline & \multicolumn{2}{|c|}{$\begin{array}{c}\text { Acetobacter aceti } \\
\text { subsp. aceti } \\
\text { NCIB } 8621 \mathrm{t}_{1}\end{array}$} & \multicolumn{2}{|c|}{$\begin{array}{c}\text { Gluconobacter } \\
\text { oxydans subsp. } \\
\text { oxydans NCIB } \\
9013\end{array}$} & \multicolumn{2}{|c|}{$\begin{array}{c}\text { Pseudomonas } \\
\text { fluorescens } \\
\text { ATCC } 13525\end{array}$} & \multicolumn{2}{|c|}{$\begin{array}{c}\text { Xanthomonas } \\
\text { campestris } \\
\text { NCPPB } 528\end{array}$} \\
\hline & $\begin{array}{l}T_{m(e)} \\
\left({ }^{\circ} \mathrm{C}\right)\end{array}$ & $\begin{array}{l}\% \text { Bind- } \\
\text { ing }\end{array}$ & $\begin{array}{l}T_{m(e)} \\
\left({ }^{\circ} \mathrm{C}\right) \\
\end{array}$ & $\begin{array}{l}\% \text { Bind- } \\
\text { ing }\end{array}$ & $\begin{array}{l}T_{m(e)} \\
\left({ }^{\circ} \mathrm{C}\right)\end{array}$ & $\begin{array}{l}\text { \% Bind- } \\
\text { ing }\end{array}$ & $\begin{array}{l}T_{m(e)} \\
\left({ }^{\circ} \mathrm{C}\right)\end{array}$ & $\begin{array}{l}\% \text { Bind- } \\
\text { ing }\end{array}$ \\
\hline $\begin{array}{l}\text { Acetobacter aceti subsp. aceti } \\
\text { NCIB } 8621 \mathrm{t}_{1}\end{array}$ & 81.0 & 0.17 & 76.0 & 0.13 & 57.0 & 0.04 & 58.5 & 0.04 \\
\hline $\begin{array}{l}\text { Gluconobacter oxydans subsp. } \\
\text { oxydans NCIB } 9013\end{array}$ & 77.5 & 0.22 & 81.5 & 0.27 & ND & ND & ND & ND \\
\hline $\begin{array}{l}\text { Pseudomonas fluorescens } \\
\text { ATCC } 13525\end{array}$ & ND & ND & 58.0 & 0.15 & 81.0 & 0.14 & 69.0 & 0.08 \\
\hline $\begin{array}{l}\text { Xanthomonas campestris } \\
\text { NCPPB } 528\end{array}$ & ND & ND & ND & ND & 69.0 & 0.07 & 81.0 & 0.09 \\
\hline Frateuria aurantia IFO 13330 & 59.8 & 0.11 & 57.8 & 0.10 & 65.1 & 0.13 & 72.5 & 0.14 \\
\hline Frateuria aurantia IFO 13333 & 60.0 & 0.08 & 60.0 & 0.10 & ND & ND & 71.0 & 0.13 \\
\hline Frateuria aurantia IFO 3249 & 59.3 & 0.10 & 61.8 & 0.12 & 66.0 & 0.10 & 72.0 & 0.11 \\
\hline \multicolumn{8}{|c|}{0.15} & 0.15 \\
\hline Acetobacter sp. IFO 3248 & 78.0 & 0.18 & 77.3 & 0.19 & $\mathbf{5 7 . 5}$ & 0.10 & 61.0 & 0.08 \\
\hline Gluconobacter sp. IFO $3246 \mathrm{t}_{1}$ & 76.8 & 0.13 & 80.3 & 0.14 & 57.0 & 0.08 & 61.0 & 0.09 \\
\hline
\end{tabular}

${ }^{a}$ DNA from the latter strains was included for comparison. A mixture of 16S and fragmented 23S rRNA had to be used from the Acetobacter and Gluconobacter strains; 23S rRNA was used from the Pseudomonas and Xanthomonas strains. $T_{m(e)}$ and percent rRNA binding have been defined in the text; ND, Not determined.

${ }^{b}$ All IFO strains were received as "Acetobacter aurantius."

DNA:rRNA duplex. The rRNA cistrons of these four strains are more similar to those of Xanthomonas and Pseudomonas than to those of Acetobacter and Gluconobacter. The rRNA cistrons of "A. aurantius" IFO $3246 \mathrm{t}_{1}$ are indistinguishable from those of Gluconobacter (15). The rRNA cistrons of strain IFO 3248 are closer to those of Acetobacter than to those of Gluconobacter.

\section{DISCUSSION}

It may be useful first to consider briefly the taxonomic conclusions to be drawn from the methods of DNA:rRNA hybridizations and protein gel electropherograms. The former method, conceived and developed in this laboratory, is most useful for grouping and identifying organisms at the levels of genus, tribe, family, and 
order. The method usually does not have enough resolution to distinguish taxa below the genus or subgenus level (11-13). It has been found that $T_{m(e)}$. the midpoint of the thermal denaturation curve of the DNA:rRNA hybrid and a measure of base differences between rRNA cistrons, is most meaningful in drawing taxonomic conclusions because it is empirically directly correlated with overall phenotypic similarities. The more the $T_{m(e)}$ value of the hybrid resembles the $T_{m(e)}$ value of the homologous duplex, the more similar are the rRNA cistrons and the more closely the organisms are related. The comparison of protein electropherograms (16; Kersters and De Ley, in press) has a different value. It has a very high resolution and is capable of detecting nearly identical strains. It is most useful in elucidating the internal taxonomic structures of genera and species.

From the three methods used (phenotypic features, protein gel electropherograms, DNA: rRNA hybridizations), we have determined unambiguously that the "A. aurantius" strains can be placed into three groups: (group 1) IFO $3246 \mathrm{t}_{1}$, (group 2) IFO 3248 , and (group 3) IFO $3245,3247,3249$, and 13328 to 13333 .

Strain IFO 3248. Hybrids between DNA from strain IFO 3248 and $\left[{ }^{14} \mathrm{C}\right] \mathrm{rRNA}$ from the type strains of the type species of Acetobacter and Gluconobacter (Table 3) have features indicating that IFO 3248 belongs in Acetobacter; this conclusion is clear from our previous extensive study on the acetic acid bacteria (15). Our phenotypic analysis (Table 2) confirms that this strain is an Acetobacter, although an atypical one.

Strain IFO 3246t $t_{1}$. Hybrids between DNA from strain IFO $3246 \mathrm{t}_{1}$ and $\left[{ }^{14} \mathrm{C}\right] \mathrm{rRNA}$ from the type strains of the type species of Gluconobacter and Acetobacter (Table 3) show unambiguously that this strain is an authentic Gluconobacter (15). Our phenotypic analysis (Table 2) of these strains confirms this. The exact taxonomic position of both strains within the genera Acetobacter and Gluconobacter is being examined and will be reported later.

Strains IFO 3245, 3247, 3249, and 13328 to 13333 . Of 99 phenotypic characters of strains IFO $3245,3247,3249$, and 13328 to 13333,77 are identical or nearly so (Table 2). The protein electropherograms of these nine strains are very nearly identical. Bacteria with similar protein electropherograms are genetically very similar (16; Kersters and De Ley, in press). We can thus conclude that the nine strains mentioned above constitute a genetically and phenotypically homogeneous group. A number of phenotypic features show that these bacteria are quite different from both Gluconobacter and Acetobacter (Table 4).

The fact that these nine strains are able to produce acetic acid from ethanol and to grow at pH 3.6 suggests superficially that taxonomically they are close relatives of Gluconobacter and Acetobacter. However, the similarity of a few phenotypic features is often an unreliable and fallacious guide in detecting relationships at the inter- and suprageneric levels. Our DNA:rRNA

TABLE 4. Features differentiating Frateuria, Gluconobacter, and Acetobacter ${ }^{a}$

\begin{tabular}{|c|c|c|c|}
\hline Feature & Frateuria & Gluconobacter & Acetobacter \\
\hline Flagellar arrangement & Polar or none & Polar or none & Peritrichous or none \\
\hline Oxidation of acetate to $\mathrm{CO}_{2}$ & - & - & + \\
\hline Oxidation of lactate to $\mathrm{CO}_{2}$ & + & - & + \\
\hline Ketogenesis & + & + & $(-)$ \\
\hline Vitamin requirements & - & + & $(-)$ \\
\hline $\begin{array}{l}\text { Formation of a yellow-brown solu- } \\
\text { ble pigment on glucose-yeast ex- } \\
\text { tract-CaCO}\end{array}$ & $(+)$ & $(-)$ & $(-)$ \\
\hline Formation of $\mathrm{H}_{2} \mathrm{~S}$ & + & - & - \\
\hline \multicolumn{4}{|l|}{ Formation from glucose of: } \\
\hline 5-Ketogluconic acid & - & + & $\mathrm{D}$ \\
\hline 2-Ketogluconic acid & + & + & $(+)$ \\
\hline 2,5-Diketogluconic acid & + & $(-)$ & $(-)$ \\
\hline Presence of ubiquinone & Q8 & Q10 & Q9-Q10 \\
\hline $\begin{array}{l}\text { Growth on Frateur's Hoyer manni- } \\
\text { tol medium }\end{array}$ & + & (-) & $(-)$ \\
\hline $\begin{array}{l}\text { Guanine plus cytosine content of } \\
\text { DNA (mol \%) }\end{array}$ & $62-64$ & $57-64$ & $51-65$ \\
\hline
\end{tabular}

" This table includes our own data, these from Bergey's Manual (7) from Yamada et al. (24, 25), Asai et al. (4), Ameyama and Kondô $(1,2)$, and Gillis and De Ley (15). Symbols: + or -: all the strains are positive or negative; $(+)$ or $(-)$ : most strains are positive or negative; $D$ : different reactions. 
hybridization method is one of the few methods which so far have been able to detect these relationships.

Our results (Table 3) show that the rRNA cistrons from strains IFO $3247,3249,13330$, and 13333 are not related to those from Acetobacter and Gluconobacter. With a $T_{m(e)}$ of about $60^{\circ} \mathrm{C}$, they cannot belong to Acetobacter or Gluconobacter and are not even members of the rRNA superfamily (15) of which these genera constitute a separate branch. Our rRNA data (Table 3) show that these nine strains do not fit in any known genus and that they belong in a separate genus. We propose to name this new genus Frateuria after the late Joseph Frateur (1903-1974), eminent Belgian microbiologist, renowned for his important contributions to the taxonomy of the acetic acid bacteria.

DNA:rRNA hybrids between DNA from strains of Frateuria and $23 \mathrm{~S}\left[{ }^{14} \mathrm{C}\right] \mathrm{rRNA}$ from Pseudomonas fluorescens ATCC 13525 and Xanthomonas campestris NCPPB 528 show $T_{m(e)}$ 's of about 67 and $72^{\circ} \mathrm{C}$, respectively. It should be stressed that the strains of $P$. fluorescens and $X$. campestris used here are type strains, each representative of a large cluster of related strains (De Vos and De Ley, manuscript in preparation). The rRNA cistrons of the Frateuria strains clearly have many base sequences in common with those from $P$. fluorescens ATCC 13525 and still more with those from $X$. campestris NCPPB 528. The genera Xanthomonas, Azotobacter, and Azomonas, the pseudomonads of Section I (7), and a few other organisms constitute a separate rRNA superfamily (12; De Vos and De Ley, manuscript in preparation). Frateuria also belongs in this rRNA superfamily. Thus, although it is taxonomically most closely related to the genus Xanthomonas, it does not belong in it. This is supported not only by phenotypic differences but also by the fact that no member of the genus Xanthomonas forms a DNA:rRNA hybrid with $\left[{ }^{14} \mathrm{C}\right]-\mathrm{rRNA}$ from $X$. campestris with a $T_{m(e)}$ below $75^{\circ} \mathrm{C}$.

Description of Frateuria gen. nov. Cell morphology. Gram-negative, straight rods, 0.5 to 0.7 by 0.7 to $3.5 \mu \mathrm{m}$, which occur singly or in pairs, rarely in filaments or as irregular cells and never in chains. Motile by means of polar flagella.

Colonial morphology. Luxuriant growth occurs on glucose-yeast extract- $\mathrm{CaCO}_{3}$ medium. After 6 days at $30^{\circ} \mathrm{C}$, the brownish colonies measure 2 to $5 \mathrm{~mm}$ in diameter, have a dark brown center, and are glistening, flat, or raised and circular with a regular edge. Some strains show a typical browning of the medium-due to a water-soluble pigment-after 3 days of incubation, others only after 6 to 10 days. The color tends to become dark coffee brown. After 4 weeks no visible crystals of Ca-gluconate are formed. Good growth is also obtained on mannitol-yeast extract-peptone agar. After 6 days at $30^{\circ} \mathrm{C}$ the colonies are yellow to orange, glistening or rough, regular or irregular, highly convex with undulate or regular edge, and 1 to $3 \mathrm{~mm}$ in diameter. They become pale brown and reach a diameter of up to $6 \mathrm{~mm}$ after 6 to 19 days.

Growth characteristics. Strictly aerobic. Growth occurs in beer wort, but in peptone broth, yeast extract broth, and Hoyer medium with mannitol, growth is faint. Growth factors are not required. Growth occurs at $\mathrm{pH} 3.6$, in a medium containing $20 \%$ glucose, and at 30 and $34^{\circ} \mathrm{C}$ but not at $4^{\circ} \mathrm{C}$. One percent ethanol is tolerated.

Susceptibility towards antibiotics. Susceptible to kanamycin $(30 \mu \mathrm{g})$, streptomycin $(10$ $\mu \mathrm{g})$, tetracycline $(30 \mu \mathrm{g})$, and novobiocin $(30 \mu \mathrm{g})$. Resistant to gentamicin $(10 \mu \mathrm{g})$, chloramphenicol $(30 \mu \mathrm{g})$, bacitracin $(10 \mathrm{U})$, penicillin $\mathrm{G}(10 \mathrm{U})$, erythromycin $(10 \mu \mathrm{g})$, lincomycin $(2 \mu \mathrm{g})$, colistin sulfate $(10 \mu \mathrm{g})$, fucidin $(10 \mu \mathrm{g})$, nitrofurantoin $(200 \mu \mathrm{g})$, methicillin $(10 \mu \mathrm{g})$, neomycin $(30 \mu \mathrm{g})$, polymyxin B (300 U), and sulfafurazole $(100 \mu \mathrm{g})$.

Biochemical features. Acid is formed from ethanol, glycerol, D-arabinose, D-ribose, D-xylose, D-fructose, D-galactose, D-glucose, and Dmannose. Acid is not produced from L-sorbose, raffinose, dextrin, or starch. With D-glucose and D-xylose, the $\mathrm{pH}$ drops below 4. The strains are ketogenic on glycerol, mannitol, and sorbitol. From D-glucose, 2-keto- ànd 2,5-diketogluconic acids are formed, but not 5-ketogluconic acid. Lactate, but not acetate, is oxidized to $\mathrm{CO}_{2}$ and water. Oxidase and gelatinase are not produced. Litmus milk is unchanged. Nitrates are not reduced. Indole is not produced. Catalase, a characteristic ubiquinone, $\mathrm{Q} 8$, and $\mathrm{H}_{2} \mathrm{~S}$ are produced.

The only species, and thus the type species, is Frateuria aurantia sp. nov. (au.ran tia, M.L. adj. aurantius gold colored; derived from aurare, C.L. verb, to overlay with gold; refers to the gold-yellow color of the strains on mannitolyeast extract peptone agar). The description of this species is the same as that given above for the genus. The type strain of $F$. aurantia is IFO 3245. A description of this strain is given in Table 2. Diagnostic features useful in differentiating Frateuria from Gluconobacter and Acetobacter can be found in Table 4 .

For the genus Frateuria as well as for its only species, Frateuria aurantia, we propose as minimal standards: gram-negative, polarly flagellated if motile, strictly aerobic rods requiring no 
growth factors, producing a brown water-soluble pigment on glucose-yeast extract- $\mathrm{CaCO}_{3}$ agar, producing the ubiquinone $Q 8$, able to grow at pH 3.6 and on Frateur's Hoyer mannitol medium, producing acid from ethanol, glucose, and xylose, and lacking oxidase, gelatinase, nitrate reduction, and starch hydrolysis; they produce $\mathrm{H}_{2} \mathrm{~S}$. From glucose, 2-keto- and 2,5-diketogluconic acids are formed, but not 5-ketogluconic acid. The guanine plus cytosine content of the DNA ranges from 62 to $64 \mathrm{~mol} \%$.

\section{ACKNOWLEDGMENTS}

J.D.L. is indebted to the Fonds voor Kollektief Fundamenteel Onderzoek for research and personnel grants, J.S. and K.K. to the National Fonds voor Wetenschappelijk Onderzoek for research grants, and F.G. to the Instituut tot Aanmoediging van het Wetenschappelijk Onderzoek in Nijverheid en Landbouw for a scholarship. We are indebted to I. Banno for kindly supplying the IFO strains.

\section{REPRINT REQUESTS}

Address reprint requests to: Prof. Dr. J. De Ley, Laboratorium voor Microbiologie, Rijksuniversiteit, Ledeganckstraat 35, B-9000 Ghent, Belgium.

\section{LTTERATURE CITED}

1. Ameyama, M., and K. Kondó. 1966. Carbohydrate metabolism by the acetic acid bacteria. V. On the vitamin requirements for the growth. Agr. Biol. Chem. 30:203211.

2. Ameyama, M., and K. Kondó. 1967. Carbohydrate metabolism by the acetic acid bacteria. VI. Characteristics of the intermediate type strains. Agr. Biol. Chem. 31: 724-737.

3. Asai, T. 1968. Acetic acid bacteria. Classification and biochemical activities. University of Tokyo Press, Tokyo.

4. Asai. T., H. lizuka, and K. Komagata. 1964. The flagellation and taxonomy of genera Gluconobacter and Acetobacter with reference to the existence of intermediate strains. J. Gen. Appl. Microbiol. 10:95-126.

5. Asai, T., and K. Shoda. 1958. The taxonomy of Acetobacter and allied oxidative bacteria. J. Gen. Appl. Microbiol. 4:289-311.

6. Bhumiratana, A., R.L. Anderson, and R.N. Costilow. 1974. Trehalose metabolism by Bacillus popilliae. J. Bacteriol. 119:484-493.

7. Buchanan, R.E., and N.E. Gibbons (ed.). 1974. Bergey's manual of determinative bacteriology, 8 th ed. The Williams and Wilkins Co., Baltimore.

8. Buchanan, R.E., J.G. Holt, and E.F. Lessel (ed.). 1966. Index Bergeyana. The Williams and Wilkins Co., Baltimore.

9. De Ley, J. 1958. Nieuwe aspecten van de oxydatieve stofwisseling van suikers in micro-organismen. Natuurwet. Tijdschr. (Ghent) 40:3-148.
10. De Ley, J., and J. De Smedt. 1975. Improvements of the membrane filter method for DNA:rRNA hybridization. Antonie van Leeuwenhoek J. Microbiol. Serol. 41:287-307.

11. De Ley, J., P. Segers, and M. Gillis. 1978. Intra- and intergeneric similarities of Chromobacterium and Jan. thinobacterium ribosomal nucleic acid cistrons. Int. J. Syst. Bacteriol. 28:154-168.

12. De Smedt, J., M. Bauwens, R. Tytgat, and J. De Ley. 1980. Intra- and intergeneric similarities of ribosomal ribonucleic acid cistrons of free-living, nitrogen-fixing bacteria. Int. J. Syst. Bacteriol. 30:106-122.

13. De Smedt, J., and J. De Ley. 1977. Intra- and intergeneric similarities of Agrobacterium ribosomal ribonucleic acid cistrons. Int. J. Syst. Bacteriol. 27:222-240.

14. Frateur, J. 1950. Essai sur la systématique des Acetobacters. Cellule 53:287-393.

15. Gillis, M., and J. De Ley. 1980. Intra- and intergeneric similarities of the rRNA cistrons of Acetobacter and Gluconobacter. Int. J. Syst. Bacteriol. 30:7-27.

15a. Gosselé, F., J. Swings, and J. De Ley. 1980. A rapid, simple, and simultaneous detection of 2 -keto-, 5 -keto-, and 2,5-diketogluconic acids by thin-layer chromatography in culture media of acetic acid bacteria. Zentralbl. Bakteriol. Parasitenkd. Infektionskr. Hyg. Abt. 1 Orig. Keihe C 1:178-181.

16. Kersters, $\mathbf{K}$., and J. De Ley. 1975. Identification and grouping of bacteria by numerical analysis of their electrophoretic protein patterns. J. Gen. Microbiol. 87: 333-342.

17. Kond6, K., and M. Ameyama. 1958. Carbohydrate metabolism by Acetobacter species. I. Oxidative activity for various carbohydrates. Bull. Agric. Chem. Soc. Jpn. 22:369-372.

18. Lanning, M.C., and S.S. Cohen. 1951. The detection and estimation of 2-ketohexonic acids. J. Biol. Chem. 189:109-114.

19. Rhodes, M.E. 1958. The cytology of Pseudomonas spp as revealed by a silver-plating staining method. J. Gen. Microbiol. 18:639-648.

20. Shriner, R.L., R.C. Fuson, and D.Y. Curtin. 1964 Systematic identification of organic compounds, 5 th ed. Wiley International, New York.

21. Skerman, V.B.D., V. McGowan, and P.H.A. Sneath (ed.). 1980. Approved lists of bacterial names. Int. J. Syst. Bacteriol. 30:225-420.

22. Sneath, P.H.A., and V.B.D. Skerman. 1966. A list of type and reference strains of bacteria. Int. J. Syst. Bacteriol. 16:1-133.

23. Swings, J., K. Kersters, and J. De Ley, 1976. Numerical analyis of electrophoretic protein patterns of $Z \mathbf{y}$. momonas strains. J. Gen. Microbiol. 93:266-271.

24. Yamada, Y., K. Aida, and T. Uemura. 1969. Enzymatic studies on the oxidation of sugar and sugar alcohol. V. Ubiquinone of acetic acid bacteria and its relation to classification of genera Gluconobacter and Acetobacter, especially of the so-called intermediate strains. J. Gen. Microbiol. 15:181-196.

25. Yamada, Y., Y. Okada, and K. Kondô. 1976. Isolation and characterization of "polarly flagellated intermediate strains" in acetic acid bacteria. J. Gen. Appl. Microbiol. 22:237-245. 